\title{
TRESPASS OR NEGLIGENCE?
}

\author{
G. H. L. FRIDMAN*
}

\begin{abstract}
The author examines the validity of distinguishing between trespass to the person and negligence, according to whether the injury was directly inflicted by or merely consequential to a negligently performed act. Whereas recent English decisions have tended to merge the two forms of action, in other Commonwealth jurisdictions, including Canada, the historical distinction has largely been retained, despite a certain amount of equivocation in the case law. One significant problem arising from any "progressive" union would be the extent to which the concepts of foreseeability, causation and other sinuosities of negligence law would be incorporated into the action. Another consideration would be whether the plaintiff would be required to satisfy a uniform burden of proof regardless of whether the injury were direct or indirect. Recognizing that "forms of action must not rule us from their graves", Dean Fridman points out that there may be good reason for not burying distinctions before their usefulness and purpose have died.
\end{abstract}

I

Does it matter which? That is clearly a question which is of concern not only to the academic, theoretical lawyer, but also the practitioner faced with the problem of how to frame the action which he is instituting on behalf of a client who has suffered personal injuries. It is with such claims that this article is concerned. As regards claims for interference with chattels or invasion of realty, the situation is even more in need of clarification, since, as I have elsewhere stated, ${ }^{1}$ recent developments in relation to personal injuries claims thus far do not appear to have been stretched so as to apply. Indeed, one aspect of these developments, which it is my present purpose to consider and discuss, may be to sharpen the distinction, which historically was tenuous, between different classes of trespass actions. Though all of these stem from the original writ of trespass vi et armis, the modern tort of trespass may now be considered to have developed three quite different sub-varieties, each with its own peculiarities, and each of which may be said to be subject to individual rules as to availability and application.

It is with trespass to the person that I am concerned, or, rather, with the nature of the remedy that is available to someone who. has been personally injured in consequence of the defendant's conduct. At the outset one distinction still remains valid: and not all the modernistic language of Lord Denning M.R., in Letang v. Cooper ${ }^{2}$ can affect this. If the injury is an indirect result or consequence of some alleged misfeasance on the part of the defendant, then it is impossible to classify or characterize the latter's conduct as trespassory. It may be negligence, if a breach of duty is involved: it may be nuisance, insofar as personal injuries are remediable in an action for nuisance: ${ }^{3}$ it may be a claim under the rule in Rylands v. Fletcher, ${ }^{4}$ again insofar as this can be said to be applicable when the plaintiff's injury is

\footnotetext{
- Dean of the Faculty of Law, The University of Alberta.

1 Fridman, Modern Tort Cases, (1968) at 228-243.

2 [1964] 2 All E.R. 929.

3 This may depend on the notion of foreseeability: The Wagon Mound (No 2) [1967] 1 A.C.617.

- (1866) L.R. 1 Ex. 265; (1868) L.R. 3 H.L. 330.
} 
personal, as contrasted with proprietary. ${ }^{5}$ Trespass is still an action that is restricted in scope to injuries that are directly inflicted by the defendant upon the plaintiff, e.g. by assault, battery, false imprisonment, and, possibly, by causing the plaintiff to suffer some nervous shock $^{6}$ or to undergo an invasion of his privacy. ${ }^{7}$

In any such action, what is the essence of the plaintiff's case, apart from his need to establish the requisite direct, and violent physical contact between the defendant and himself? Must he also aver and prove an intent to injure? Will it suffice to show that the defendant, while not wilful in his actions, was at least negligent; and, if so, what is involved in any such allegation of negligence? Or need the plaintiff prove either wilfulness or negligence, in addition to the necessary acts and consequences, for him to make out at least a prima facie case of trespass? "Prima facie" may be a valid qualification since the defendant may be able to negate or repudiate liability by establishing some recognized answer such as his insanity at the material time (which may involve proof of utter incapacity to understand or appreciate what he was doing, or may only require proof of an incapacity to appreciate the quality, if not the nature of his act), ${ }^{8}$ or the prior consent of the plaintiff to the trespass involved, insofar as such assent may be legally acceptable, ${ }^{9}$ or, possibly, the contributory negligence of the plaintiff, perhaps in the form of provocation of the defendant's attack upon him, to the extent to which such provocation is a valid defence in law, or only a factor affecting the quantum of damages payable by the defendant. ${ }^{10}$

English, Australian, and Canadian cases over the past twenty years provide some interesting contrasts, and invite the conclusion that the common law, whatever else it may be, is not necessarily common throughout all those countries which profess to apply it in the twentieth century. There is some conflict of views in respect of the nature of trespass, and, in particular, the question of burden of proof. I want to consider not only the differences of opinion that have been expressed as to the former, but also the practical consequences of the differences of opinion that have been manifested in respect of the latter. Contrary to the view put forth in 1959 by one commentator 11 upon the decision of Diplock $J$., as he then was, in the case of Fowler v. Lanning, 12 this is not a matter that is "of less practical importance" while being "of greater academic interest". I hold to the view that onus of proof is an important practical question, and this is supported by the judgment of the Manitoba Court of Appeal in the recent case of Dahlberg v. Naydiuk ${ }^{13}$ which, with other relevant authorities will

\footnotetext{
s Perry v. Kendricks Transport [1956] I All E.R. 154; Benning v. Wong (1969) 43 Aust. L.J.R. 467, per Barwick C.J., Menzies and Windeyer JJ.

- Wilkinson v. Downton [1897] 2 Q.B. 57; Janvier v. Sweeney [1919] 2 K.B. 316.

7 Robbins v. Canadian Broadcasting Corporation (1957) 12 D.L.R. (2d) 35.

- Morriss v. Marsden [1952] 1 All E.R. 925, and, generally, Fridman, Mental Incompentency, (1964) 80 L.Q.R. 84 at 87.96

- Wright v. McLean (1956) 7 D.L.R. (2d) 253; Hartley v. Chaddock (1957) 11 D.L.R. (2d) 705. This may be bound up with the wider question of the application of maxim ex turpi causa non oritur action in the context of tort generally: I.C.I. v. Shatwell [1965] A.C. 656: Smith v. Jenkins (1970) 44 Aust. L.J.R. 78.

10 Lane v. Holloway [1967] 3 All E.R. 129; Bruce v. Dyer (1966) 58 D.L.R. (2d) 211; Fontin v. Katapodes (1962) 108 C. L. R. 177.

"1 (1959) 75 LQ.R. 161.

12 [1959] 1 All E.R. 290.

is (1970) 10 D.L.R. (3d) 319.
} 
be considered in detail below. This is, therefore, a topic of general, and not merely specialized interest and relevance.

\section{II}

There appear to be two questions for consideration. The first is whether there still exists in the law such a tort as trespass to the person, where the alleged trespass was inflicted negligently. The second relates to the nature of the burden of proof of the ingredients of the tort, if the wrong committed by the defendant may be described as trespass. An examination of the modern authorities-and it is with these that I am concerned, since the older situation was clear, but is not necessarily applicable today-reveals that these two questions are but different aspects of the same issue. There is no problem of onus of proof if there is no distinct and separate tort of trespass to the person: for, if it is accepted that trespass merges with negligence, in appropriate instances, it must follow that the relevant rules to apply, at any rate so far as establishing the plaintiff's case is concerned, are those applicable to negligence. The same may not be true of substantive matters (of which more will be said later): but in relation to proof, there can be no distinction between negligence stricto sensu and what may be called either trespassory negligence or negligent trespass.

This is the end result of the gradual evolution contained in the modern English cases. It is now a far cry from the days when trespass and trespass on the case (or negligence in modern parlance) were sharply differentiated and an action could be decided on whether the appropriate writ was trespass or case where, for example, the plaintiff's injury came about because of the explosion of a squib which was thrown by the defendant at $X$, immediately thrown away by $X$ to land near $Y$, and then thrown by $Y$ so as to land near, and explode in the face of the plaintiff, ${ }^{14}$ or the plaintiff was injured by the plaintiff's carriage being driven by the defendant's servant and everything turned upon whether the defendant was present with the servant or sitting in his home while the servant drove the carriage on his behalf.15

The reforms that occurred in mid-nineteenth century made such niceties of pleading of historical interest only. But they did not exorcise all the devils of the old common-law writ system. However, the relaxation that took place with respect to the formalities of pleading could not, and did not affect the more substantial differences that existed between different types of action. Whether the appropriate action was trespass or case: whether neither, either, or both were available to the plaintiff: there still remained the question whether there was any essential difference between these actions or remedies. Diplock J., as he then was, put the matter succinctly in Fowler v. Lanning ${ }^{16}$ when he said:

It is fashionable today to regard trespass to the person as representing the historic principle that every man acts at his peril and is liable for all the consequences of

14 Scott v. Shepherd (1773) 3 Wilson 403.

is Day v. Edwards (1794) 5 T.R. 648; Leame v. Bray (1803) 3 Ext. 593; Cowell v. Lanning (1808) 1 Camp. 497; Williams v. Holland (1833) 10 Bing. 112; Sharrod v. London \& North Western Ry. Co. (1849) 4 Ex. 580.

is Supra, n. 12 at 293. 
his acts; negligence as representing the more modern view that a man's freedom of action is subject only to the obligation not to infringe any duty of care which he owes to others.

On that basis, there would be a definite, and important distinction between a trespassory personal injury and one remediable by an action for negligence. Indeed, this was the basis of the plaintiff's claim, and the reason for the judgment of the court, in Fowler v. Lanning. The plaintiff had suffered injuries resulting in the loss of his left eye when he was shot by the defendant during the course of a shooting party. He brought an action in respect of such loss, the statement of claim in which he merely put, baldly and succinctly, that the defendant shot the plaintiff whereby the plaintiff suffered injury, without containing allegations of intent to injure or negligence. In consequence the defendant objected that the statement of claim disclosed no cause of action, and pursued a procedural course which, formerly, would have involved a demurrer: he raised a preliminary point of law. It became necessary to decide whether it was sufficient for the plaintiff to allege (and therefore be obliged to prove) only a direct physical "attack" (in the sense of conduct which immediately affected the plaintiff's personal safety) upon him, without establishing any more clearly "unlawful" conduct, that is, an intentional assault or a negligent breach of any duty of care.

To the argument that the plaintiff alleged trespass to the person, therefore it sufficed to aver, and be prepared to prove by evidence, the direct physical contact between defendant and plaintiff arising from the defendant's conduct, in this instance his shooting a gun at the party, Diplock J. rejoinded that since 1617, when Weaver v. Ward ${ }^{17}$ was decided, it had never been the case that a man acted at his peril so as to give rise to liability for trespass wherever his act directly resulted in physical injury to another. The cases since then, notably those involving injuries arising out of highway accidents, but not only those, revealed that either an intention to injure was essential or, at the very least, some negligence. This was ultimately approved in the famous, or infamous case of Stanley v. Powell, 18 which has been much criticized.19 There, as in Fowler v. Lanning, the plaintiff was injured, on private property, not the highway, in a shooting accident, and the court held that, failing proof of negligence, which the jury negatived by its decisions, and in the absence of any allegation of intentional infliction of the injuries, an action for trespass would not lie. Stanley v. Powell, after some sixty years, was approved by the Court of Appeal in a case of trespass to land (or chattels), and therefore not exactly on the point now in issue, in National Coal Board v. J.E. Evans \& Co. (Cardiff) Ltd. \& Maberley Parker. ${ }^{20}$ Hence Diplock J. felt constrained by history, principle and authority to decide that, in modern times, trespass to the person required an allegation, and proof, of some intent to injure or negligence: (though he left open for decision what precisely was meant by the expression 'negligence' in this context-in respect of which all that the

17 (1616) Hob. 134.

18 [1891] 1 Q.B. 86.

10 Notably in the 15th Edition of Pollock on Torts at 128 by the editor, P.A. Landon, and also in Beals v. Hayward [1960] N.Z.L.R. 131 at 136.

20 [1951] 2 K.B. 801; itself approved and applied by O'Keefe J. of the High Court of the Republic of Ireland in Electricity Supply Board v. Hastings \& Co. Ltd. (1965) 31 Ir. Jur. 51. 
learned judge said"1 was that earlier discussion of the notion of "inevitable accident" or negligence in connection with trespass to the person had taken place before the days of judges "to whom modern concepts of negligence, contributory negligence, and causation were familiar", suggesting by this, possibly, that such terms were being loosely used, and might need re-examination in the light of modern developments).

To some people a wink is as good as a nod. To no judge does this apply more aptly than Lord Denning M.R. Certainly there is evidence of this in his judgment in Letang v. Cooper. ${ }^{22}$ There the suggestions thrown out by Diplock J. (who by 1964 was in the Court of Appeal which heard the Letang case) in Fowler v. Lanning were taken up and developed. The later case was concerned with the interpretation of a statute dealing with limitation of actions. By virtue of certain amendments that had been made to the Limitation Act, $1939^{23}$ there was a distinction between actions in "tort" and actions specifically for personal injuries. When the plaintiff was injured by the defendant's running over her with his car, she sued in trespass, more than three years after the incident, and therefore outside the time within which she should have brought her action if it came within the later statutory amendment, alleging that her action, being for trespass to the person, was an action in "tort", so as to be within the earlier Act. It was held that the subsequent legislation, on a proper interpretation, included all actions for personal injuries, on whatever basis they were brought: therefore the action was statute-barred.24 Strictly speaking, therefore, it was not necessary for the court to discuss the trespass/ negligence point. However, the members of the Court of Appeal, in particular Lord Denning M.R., went beyond the statutory point and took up the whole question of the inter-relationship of trespass and negligence in the modern law of torts. Lord Denning ${ }^{25}$ adverted to the obsolete nature of the trespass-case dichotomy. Instead of dividing actions for personal injury into trespass (direct damage) or case (consequential damage) the modern division should be, and is according to Lord Denning, dependent upon whether the defendant did the injury intentionally or unintentionally. The former is assault and battery, that is, trespass to the person. In the latter situation there is no trespass; there is only a cause of action in negligence, and then only on proof of want of reasonable care. Indeed Lord Denning stated, “... when the injury is not inflicted intentionally, but negligently, ... the only cause of action is negligence and not trespass." Thus Lord Denning goes to the extreme, perhaps it might be said the logical extreme, of concluding that negligently inflicted personal injuries, whether directly or consequentially inflicted are only remediable by an action for negligence, so that in such circumstances the action for trespass is irrelevant and inapplicable. With the ultimate result Diplock

\footnotetext{
"Fowler v. Lanning, supra, n. 12.

22 Supra, n. 2.

23 By the Law Reform (Limitation of Acts, etc.) Act, 1954.

24 In this respect following an Australian case, from the State of Victoria, dealing with a similarly worded local statute: Kuber v. Grzesiak [1963] V.L.R. 621, with which contrast Williams v. Milotin (1957) 97 C.L.R. 465, discussed below. The problem has been solved in Alberta by the amendment to the Limitation of Actions Act, R.S.A. 1955, c. 177, contained in S.A. 1966, c. 49, 8. 51 making two years the period of limitation for trespass and negligence actions involving personal injury.

2s Supra, n. 2 at 932.
} 
L.J. agreed. But the learned Lord Justice preferred to maintain a theoretical distinction between trespass to the person and negligence, even though there was no real effect in such distinction. Where $\mathbf{A}$ by failing to exercise reasonable care inflicted direct personal injuries on $B$, then this factual situation could be indifferently described as a cause of action in negligence or a cause of action in trespass, and the action itself as either for negligence or trespass to the person. ${ }^{26} \mathrm{He}$ agreed, however, that "negligence" was the preferable expression. But there was only one cause of action, there were not two distinct ones. That there might be two denominations of this action was irrelevant: it did not cease to be "negligence", that is, the tort of negligence, because it could also be called by another name. "An action founded on it is none the less an 'action for negligence' because it can also be called an 'action for trespass to the person"'.27 These two judgments, therefore, support the conclusion that, in the modern English law of torts, there is no such animal as an action for trespass to the person where personal injury is inflicted negligently.

What is the reason for this development? The judgments in the Letang case would suggest purely technical change in the nature of pleading; or, if it be preferred, a more correct appreciation of the difference between 'cause of action' and 'form of action'. This, with respect, is only the outward trappings. Underlying the reasoning of the court is the idea, expressed obiter by Lord Macmillan in Read v. Lyons $^{28}$ in 1947, that for personal injuries negligence must be proved before recovery is permitted. Modern courts do not seem to favour the view that the infliction of personal injury (even where there is no legal excuse for such infliction) ought to substantiate an action without something more, in other words, some proof of improper conduct. It is true that this appears to be belied by, on the one hand, the continued application of doctrines of "strict liability", and, on the other, the interpretation of some statutory duties, notably where factories and factory employees are concerned, in a fashion which precludes the necessity for establishing a negligent breach before liability will arise. However, as against this, it may be said that there has been an amelioration of the stricter aspects of so-called strict liability, as witness, for example, the decision in The Wagon Mound (No. 2):29 and that there are special reasons for imposing some strict form of liability for breaches of a statute designed to protect employees (which, after all, do involve what is prima facie illegal conduct since it is a failure to perform a duty imposed by statute in the interests of a substantial section of the community who are particularly susceptible to injury and require adequate protection if their safety is to be ensured in dangerous situations). Despite these developments, there is still prevalent in the courts in England the notion that, as far as possible, liability ought to be founded upon some reprehensible behaviour. It is interesting to note, as has been pointed out and discussed by Professor Charles O. Gregory, ${ }^{30}$ that as early as 1850 an American court took the same view, when Shaw C.J. of the Supreme

\footnotetext{
${ }^{28}$ Id., at 935 .

27 Id.

28 [1947] A.C. 156 at $170-171$.

29 Supra, n. 3. Fridman, The Rise and Fall of Rylands v. Fletcher, (1956) 34 Can. B.R. 810.

30 Trespass to Negligence to Absolute Liability, (1951) 37 Va. L.R. 359.
} 
Judicial Court of Massachussetts decided the case of Brown v. Kendall ${ }^{31}$ (which involved injuries resulting from an attempt by two men to separate their fighting dogs). Since that date, as Professor Gregory explains, American decisions have shifted their course more than once; in fact the result has been to undermine the clear-cut principles of Chief Justice Shaw, and to leave it uncertain whether the governing principle is one of strict, or, in Professor Gregory's term 'absolute' liability, or is one of no absolute liability (except, possibly, for the consequences of extrahazardous conduct or on the basis of outright enterprise liability analogous to that reflected in such statutes as the Workmen's Compensation Act). ${ }^{32}$ As this discussion makes clear, there are many factors which are relevant to the issue whether liability for personal injuries should be strict or absolute on the one hand, or founded upon some kind of fault on the other. American courts appear to be unresolved on this issue. The apparent certainty to be found in Letang v. Cooper is open to question in the light of what has been mentioned above as to the vestigial (and perhaps, in a modern sense and context, revived) traces of strict or absolute liability in English law.

If there can be doubt as to the present situation in English law with regard to personal injuries (and there is even greater doubt with respect to injuries to chattels or to land) the cases in Commonwealth countries generally, outside the original home of the common law, provide evidence of even greater uncertainty and disparity.

Between 1959, when Fowler v. Lanning was decided, and 1964, when the Letang case came before the Court of Appeal, McGregor J. of the Supreme Court of New Zealand heard the case of Beals v. Hayward. ${ }^{33}$ This case was really concerned with the problem of intention in trespass, rather than with negligence. But it is relevant in that the learned judge accepted the reasoning and arguments of Diplock J. to the extent of stating ${ }^{34}$ that "to succeed in a claim for personal injury there must be intentional aggression or negligent default on the part of the defendant". The decision in this court, therefore, supports the contention that trespass to the person is not a wrong that involves strict or absolute liability. The way in which the New Zealand judge adopted the language of Diplock J. suggests that a later case in that jurisdiction, if faced with the problem, would be prepared to adopt the wider-reaching, further advanced arguments of the Court of Appeal in Letang v. Cooper. This is admittedly, a matter of speculation. Reading the judgment of the New Zealand court, however, it would seem likely that, in view of what was said in relation to the problem of burden of proof (which will be discussed later), the ultimate development, namely to make trespass otiose where the plaintiff alleges a negligent interference with his personal safety, would be acceptable to a New Zealand court if and when the issue arose.

The same cannot be submitted with equal confidence with respect to the courts in Australia. In an early case, Blacker v. Waters, ${ }^{35}$ in

${ }^{31}(1850) 60$ Mass. 292.

32 Gregory, supra, n. 30 at 396.

33 [1960] N.Z.L.R. 131, in which the defendant shot the plaintiff in circumstances which raised the issue of the defendant's intent, that is, his state of mind, in view of his_disease of the mind, ultimately resolved in favour of the non-liability of the defendant. Fridman, Mental Incompetency, (1964) 80 L.Q.R. 84 at 89.

34 Beals v. Hayward, supra, n. 33 at 138-139.

35 (1928) 28 S.R. (N.S.W.) 406. 
1928, the Court of Appeal of New South Wales held that trespass was prima facie actionable where the plaintiff established that he had been hit in the eye by a piece of lead coming from a bullet fired by the defendant at a shooting gallery. Hence was raised the issue of onus of proof of lack of intent or negligence (in respect of which the court found in favour of the plaintiff, holding that the defendant had not established that he was guiltless). Some thirty years later, in Williams v. Milotin, ${ }^{36}$ the High Court of Australia, on appeal from the Supreme Court of South Australia, in a case which raised precisely the same point, with respect to legislation on periods of limitation, as did the case of Letang v. Cooper, held that trespass to the person was a distinct type of wrong from negligence; and it had remained distinct notwithstanding changes in the law of procedure, alterations in regard to limitation periods, or the substantive developments which have taken place this century with respect to negligence liability. In the light of the subsequent language of the Court of Appeal in Letang v. Cooper, it is instructive to cite at length this passage from the judgment of the Full Court (Dixon C.J., Williams, Webb and Kitto JJ.): $: 37$

The two causes of action are not the same now and they never were. When you speak of a cause of action you mean the essential ingredients in the title to the right which it is proposed to enforce. The essential ingredients in an action of negligence for personal injuries include the special or particular damage-it is the gist of the action-and the want of due care. Trespass to the person includes neither. But it does include direct violation of the protection which the law throws round the person. It is true that in the absence of intention of some kind or want of due care, a violation occurring in the course of traffic in thoroughfare is not actionable as a trespass. It is unnecessary to inquire how that comes about. It is perhaps a modification of the general law of trespass to the person. But it does not mean that trespass is the same as actionable negligence occasioning injury. It happens in this case that the actual facts will or may fulfil the requirements of each cause of action. But this does not mean that ... only one 'cause of action' is vested in the plaintiff.

What these sentences reveal is that the Australian High Court was eager to maintain the difference between negligence and trespass. It is interesting to observe that the purpose of such differentiation, in this case, was to establish that the plaintiff's cause of action was in negligence, so as to entitle him to sue within six years of the accident in which he was injured, rather than in trespass, which would have given him only three years within which to sue, so as to render him outside the period of limitation. In the later English case, it will be remembered, the effect was quite different, since the action for negligence was statute-barred after the shorter, rather than the longer period. This raises the question: would the Australian court have been so anxious to sharpen the distinction between trespass and negligence had the periods of limitation been ordered differently? Perhaps this is an unfair question, since the reasoning of the court in Williams v. Milotin was based upon the language of the South Australian statute, which retained the older terminology of the common law and spoke of trespass upon the case and trespass, whereas in Letang v. Cooper the statutory language involved revealed an entirely different, more modern

30 (1957) 97 C.L.R. 465, with which contrast Kuber v. Grzesiak [1963] V.L.R. 621.

37 Williams v. Milotin, supra, n. 36 at 474. 
approach to the problem of actions for personal injuries. ${ }^{38}$ However, a few years later, when the nature of trespass to the person was again considered by a judge of the High Court, in this instance Windeyer $J$., it arose in relation to the issue of burden of proof, and the difference between trespass and negligence was again underlined, even though the learned judge, following earlier Australian and English authority, was prepared to accept that a case of trespass to the person could not be sustained if there was neither an intent to injure nor negligence in failing to avoid injury. ${ }^{39}$

That case reaffirms the Australian opinion that trespass to the person is an entirely distinct variety of action, subject to its own rules as to the nature of liability and the problems of proof. It would appear from a study of the Canadian cases from Parukey v. Parukey \& Yule $^{40}$ in 1945 down to Dahlberg v. Naydiuk ${ }^{41}$ in 1970 that courts in this country have also taken the view that trespass and negligence must be differentiated, even though trespass does not involve any strict or absolute liability. The first of the cases mentioned above is one in which it was said that a trespass could be the result of negligent conduct (therefore contribution between two negligent tortfeasors under the British Columbia Contributory Negligence Act could be permitted in a trespass action). This seems to have been denied in Eisener v. Maxwell, ${ }^{42}$ where members of another court put forward the views that assault involves some intention, ${ }^{43}$ and that not only are highway accidents always instances of negligence, not assault or battery, but all negligent batteries are remediable by actions for negligence, not battery, that is, trespass. ${ }^{44}$ However in the Supreme Court of Canada in the same year, 1951, in Cook v. Lewis, ${ }^{45}$ the famous case of the plaintiff who was shot by one of two hunters though it was never discovered by which one, Cartwright J. (with whom Estey and Fauteux JJ. agreed) applied the case of Stanley v. Powell with respect to onus of proof in a manner which indicated that these judges accepted the difference between trespass and negligence and the applicability of trespass in a proper instance. ${ }^{46}$ Several later cases take up the issue of burden of proof (and therefore need no full discussion for the moment) in language which clearly shows that Canadian courts were not assimilating trespass and negligence despite what was said in Eisener v. Maxwell, or later in Letang v. Cooper in England. Indeed one leading Ontario case, Hollebone v. Barnard ${ }^{47}$ repudiates the argument and conclusion in the Parukey case, and holds that trespass actions are not within the Contributory Negligence Act (in Ontario at any rate), thereby making the defence of contributory negligence inapplicable to actions of trespass to the person. In coming to this conclusion the court stressed that trespass would seem to be distinct from negligence even though trespass may be committed negligently. This

\footnotetext{
3s Hence compare the Victorian case cited supra, n. 36.

5o McHale v. Watson (1964) 111 C.L.R. 384, upheld on appeal on other grounds [1966] Argus L.R. 513.

${ }^{40}$ [1945] 4 D.L.R. 81.

"Supra, n. 13.

${ }^{42}$ [1951] 3 D.L.R. 345.

43 Id., at 346 per Doull J.

4 Id., at 356 per MacDonald J.

4s [1951] S.C.R. 830.

4 Id., at 839 .

${ }^{47}$ [1954] O.R. 236.
} 
is an attitude which is also clearly apparent in the most recent case, Dahlberg v. Naydiuk, ${ }^{48}$ even though the Manitoba Court of Appeal refuse to accept that trespass to the person involves any strict or absolute liability. Relying on Stanley v. Powell as well as several Canadian cases, ${ }^{49}$ the court held that, even where injuries resulted from the use of a gun by a hunter (not in itself prima facie an unlawful activity-which is a most relevant factor, since there might be a difference if the defendant is engaging in some unlawful conduct as a consequence of which he injures the plaintiff, albeit unintentionally, and maybe even without negligence), there was no absolute or strict liability for the consequences of such use of such conduct.50 But the court did recognize that there was a distinction between an action framed in trespass and one framed in negligence-even though such difference gave rise to anomalies of which more will be said later. It would seem reasonable to conclude, therefore, that Canadian courts, like those of Australia, have not been willing to accept the more advanced thinking of the English Court of Appeal, as manifested in Letang v. Cooper.

There is indeed one, if not more than one, difficulty standing in the way of any such assimilation of trespass and negligence as was suggested in the English case. I have adverted to it elsewhere, ${ }^{51}$ but it merits repetition. This is the problem of defining what is meant by "negligence" in the context of trespass. It is well known and accepted that the concept of negligence is complex and involved. Any reader of the multitude of cases which have been concerned with the definition and application of this tort, and many practitioners, as well as all law students, who have been compelled to pour over such cases, will be aware of the difficulties arising from an understanding of such matters as 'duty of care', causation, remoteness, and foreseeability. Are these problems to be imported into the law relating to trespass? Or is the effect of the English development to make it necessary to consider only whether the defendant was "careless", in a general, colloquial sense, not necessarily in the more technical sense of "in breach of a duty of care owed by him to the plaintiff'? A close reading of Letang v. Cooper would suggest the former to be the correct interpretation of that case. Is this legitimate or justified? Only if it is now considered valid to repudiate the old-fashioned differentiation between direct and indirect injuries. The modern approach would appear to be founded upon the idea that this archaic distinction is outmoded: that in a modern age there is no possible basis upon which the law ought to take into account whether the defendant directly or indirectly harmed the plaintiff: since, either way, the sole question should be whether the harm he inflicted was inflicted in a manner deserving of blame. In this respect "carelessness" would be insufficient. All the paraphernalia of the tort of negligence become relevant and meaningful in relation to erstwhile trespasses to the person.

III

Such a drastic evolution may not be universally approved, even though the view has been expressed that the present distinction be-

so Supra, n. 13

49 Whalen v. Bowers [1925] 3 D.L.R. 442; Cook v. Lewis [1951] S.C.R. 830; Lange v. Bennett (1964) 41 D.L.R. (2d) 611, contrast Nordstrom v. McBurnie (1968) 63 W.W.R. 626, criticized by the Manitoba Court of Appeal. 
tween trespass and negligence produces anomalous, and inelegant results. ${ }^{52}$ This particular critic of the existing situation (or at any rate the existing situation outside England) had in mind the problem of burden of proof, in respect of which a clear difference has emerged between English courts and those of Commonwealth countries. Possibly this difference has led to the more revolutionary view taking root in English courts. As long as courts outside England adopt the view which they have done with respect to burden of proof, it will not be possible for trespass and negligence to be assimilated: and it will not be necessary to determine definitively whether 'carelessness' or 'negligence' is the test of liability. Indeed, one benefit, if such it may be described, of the present position as regards burden of proof in countries such as Canada is that a clear distinction can be drawn between the requirements of 'negligence' stricto sensu, where that tort is in issue, and the element of negligence in the sense of carelessness, which appears to be what is relevant in relation to trespass at the present time. This becomes clear when an examination is made of the cases concerned with the issue of burden of proof.

So far as the situation in England is concerned, Diplock J. subjected the historical development to some analysis in Fowler v. Lanning, ${ }^{53}$ in which the issue of burden of proof was vital. He made a number of different points. First, there was the inconclusiveness of the cases decided prior to the changes made by the Common Law Procedure Acts in the nineteenth century. While some ${ }^{54}$ suggested that a plea of not guilty, that is, the general issue, rendered it necessary for the plaintiff to establish the unlawfulness of the defendant's conduct, in other words whether he deliberately or negligently injured the plaintiff, there were others ${ }^{55}$ which made it requisite for the defendant to plead certain defences, such as "inevitable accident" (which seems to have its origins in the case of Weaver $v$. Ward $)^{56}$ specially. But the modes of trial, and the elements of the different torts involved, were such that, in the end, the result was the same, and there was no trace in the reports "that the possibility that the onus of proof might be different in the two classes of cases was a question which ever occurred to the judges of those days, or that their charge to the jury differed according to whether the action were framed in trespass or in case". 57 Secondly, there was the development with regard to accidents on the highway, in respect of which the cases showed that proof of negligence, averred and established by the plaintiff, was essential for liability to exist.58 When Stanley v. Powell came to be decided, the issue was raised whether accidents off the highway should be viewed in the same way as accidents on the highway: in the event, according to Diplock J., the decision in Stanley v. Powell was neutral on

so Supra, n. 13 at $325-327$.

s) Fridman, supra, n. 1 at 226-228.

s2 Wright, Res Ipsa Loquitur, in Linden, Studies in Canadian Tort Law at 46.

ss Supra, n. 12 at $294-297$.

st Gibbons v. Pepper (1695) 1 Ld. Raym. 38; Wakemain v. Robinson (1823) 1 Bing. 213.

ss Knapp v. Salisbury (1870) 2 Comp. 500; Hall v. Fearnley (1842) 3 Q.B. 919.

se (1616) Hob. 134.

37 Supra, n. 12 at 295 .

so Fletcher v. Rylands (1866) L.R. 1 Ex. 268 at 286 per Blackburn J.; Holmes v. Mather (1875) L.R. 10 Ex. 261 , at 268 per Bramwell B; River Wear Commissioners v. Adamson (1877) 2 A.C. 743 at 767 per Lord Blackburn; Gayler \& Pope Ltd. v. B. Davies \& Son, Ltd. [1924] 2 K.B. 75 at 82 per McCardie J. 
the question of onus of proof. The result and effect of the reasoning of Diplock J. was that the onus of proving negligence, where the trespass is not intentional, lies on the plaintiff, whether the action be framed in trespass or in negligence. In deciding this, the learned judge seems to have been moved by the ultimate justice of this attitude. "It offends the underlying purpose of the modern system of pleading", he said,59 "that a plaintiff, by calling his grievance 'trespass to the person' instead of 'negligence', should force a defendant to come to trial blindfold." Here the learned judge is emphasizing the procedural aspects of the difference. In Letang v. Cooper, ${ }^{60}$ it would seem that the Court of Appeal, while endorsing Diplock J.'s views, was looking more at the substantive law than at the procedural aspects of any possible difference between trespass and negligence. This was, therefore, a further step, as already discussed, in the reasoning which led English courts towards the more advanced revolutionary view already considered.

There is a sharp contrast in cases from Commonwealth countries. As might be expected, in the light of what has been said earlier, the New Zealand Judge, McGregor J., in Beals v. Hayward,61 agreed with the approach of Diplock J. in Fowler v. Lanning. After quoting extensively from the judgment in that case, and then referring to the decision of the Supreme Court of Canada in Cook v. Lewis ${ }^{62}$ (of which more will be said later), the learned New Zealand judge noted that both Diplock J. and Cartwright J., of the Supreme Court of Canada relied upon the controversial case of Stanley v. Powell for opposite conclusions as to the law. While Diplock J., as seen, placed the onus on the plaintiff, Cartwright J., suggested that it was for the defendant to excuse himself by proving no negligence (or intent), subject to an exception where the injury was inflicted on the highway (which was an historical distinction still to be maintained, not the basis for a modern rationalization, as Diplock J. had made it in Fowler v. Lanning). In respect of this $\mathrm{McGregor} \mathrm{J}$. said:63

But the view that the law relating to accidents on the highway might be distinguishable from accidents on private property was rejected by the Court of Appeal in National Coal Board v. J.E. Evans and Co. (Cardiff) Ltd. ${ }^{64}$ It does seem to me that the general rule that he who affirms must prove is applicable, although in many cases proof that the defendant did the act and that the plaintiff was thereby injured may warrant the inference that the act was intentional on the part of the defendant. Similarly, when injury to the person is a direct consequence of an act of the defendant, and a claim is based on negligence, the onus of proof of such negligence lies on the plaintiff.

No distinction could be made in this respect between what happened on private property and what happened on the highway. Nor could any distinction be made between intentional and negligent trespass. Dicta which suggested that the onus of disproving negligence lay on the defendant were explicable on the basis of the application of the doctrine of res ipsa loquitur to the particular circumstances, or because there was an irresistible inference of lack of care.

\footnotetext{
so Supra, n. 12 at 298.

- Supra, n. 2.

61 [1960] N.Z.L.R. 131.

e2 Supra, n. 45.

os Supra, n. 61 at $160-161$.

4t [1951] 2 K.B. 861: and gee Electricity Supply Board v. Hastings \& Co. Ltd. (1965) 31 Ir. Jur. 51.
} 
The Australian view is quite different. Before the decision in Fowler v. Lanning the New South Wales Court, in Blacker v. Waters ${ }^{65}$ held that the burden of establishing that a prima facie trespass, by shooting, was neither intentional nor the result or negligence lay upon the defendant. This view, based upon the judgment of Denman J. in Stanley v. Powell, as well as such older authorities as Weaver v. Ward, was upheld by Windeyer J., of the High Court of Australia in McHale v. Watson, ${ }^{66}$ in the teeth of the reasoning of Diplock J., in Fowler v. Lanning. Windeyer J. preferred the old statement in Weaver v. Ward that "No man shall be excused of a trespass except it be adjudged utterly without his fault." These latter words meant, as the context of later decisions (rather than the context of the actual decision in which a plea that the defendant had accidentally, by misadventure and involuntarily, discharged his musket was demurrable) made clear, not an absence of all ground for blame and censure of any kind but an absence of such negligence as constituted fault in law. ${ }^{67}$

Canadian decisions are not unanimous: nor are they unequivocal. In Cook v. Lewis, ${ }^{68}$ three members of the Supreme Court (Cartwright, Estey and Fauteux JJ.) held that the plaintiff was entitled to succeed against both alleged wrongdoers, even though the one who was solely guilty of injuring him could not be identified, on the application of the Stanley v. Powell doctrine that, once trespass was prima facie established, the onus lay on the defendant, in this instance on each of the defendants, to establish the absence of intention and negligence. It must be noted, however, that in this difficult case, at least one other among the majority in favour of the success of the plaintiff came to that conclusion upon an entirely different basis, and one member of the court dissented on the ground that it was necessary for the plaintiff to make out a case against either defendant or both of them if he was to be able to recover damages in respect of his injury. So the decision in this case is by no means authoritative and decisive. The problem was left undecided by the case of Walmsley v. Humenick ${ }^{69}$ in 1954, in which Clyne J. of the Supreme Court of British Columbia discussed the law relating to trespass in great detail in the context of an injury inflicted on one child by another (a frequent occasion for such discussions, as witness McHale v. Watson as well as the Canadian cases discussed herein). Clyne J. was primarily concerned with the question whether a child could be liable, which depended upon whether trespass was a wrong of strict or absolute; or other liability. Having decided that intention or negligence was an essential ingredient of trespass liability, the learned judge did not have to determine any question of onus of proof, since earlier, in the course of deciding the plaintiff's claim as based upon negligence, apart from trespass, he had held that the particular infant in this case was incapable of being found guilty of negligence. Whether the plaintiff had to prove negligence, therefore, or the defendant to disprove it, was irrelevant on the facts of this case, since the age of the defendant precluded any finding of negligence against him: unlike the case of McHale v. Watson,

\footnotetext{
os Supra, n. 35.

supra, n. 39.

a7 Id., at 388.

so Supra, n. 45.

6 [1954] 2 D.L.R. 232
} 
where the age of the infant was such that he could be found liable for negligence, though the Full High Court was divided over the question whether the appropriate test was the reasonable adult or the reasonable infant of the age of the defendant.70 A more definite view is to be found in the Ontario case of Tillander v. Gosselin, ${ }^{11}$ where a child aged three was held not liable in trespass, since the child was not capable of formulating any intent to injure and could not be held guilty of negligence. Grant J. stated categorically that the onus was on the defendant of disproving intent or negligence in a case of assault. ${ }^{72}$ More recently, again in Ontario, but this time in an action brought against an adult, Brooke $J$. held that once a battery was proved to have occurred, the onus was on the defendant to show that it had happened without any negligence on his part. This case, Ellison v. Rogers, ${ }^{73}$ was one in which the defendant hit the plaintiff with a golf ball while they were both on the course. In the latest case, Dahlberg v. Naydiuk, ${ }^{74}$ where a hunter, firing over land without the permission of the owner (and thereby committing trespass to such land) hit the plaintiff, the owner of the land in question, it was held that this was prima facie trespass, therefore the onus was on the defendant to prove lack of negligence on his part. Since the evidence at the trial did not exonerate the defendant from guilt of negligence, it was held that the plaintiff's claim was properly successful at first instance and the appeal should be dismissed. It is interesting in the present context to note the acceptance by the Manitoba Court of Appeal of the point of view expressed in Cook v. Lewis as to onus of proof, even though the irrationality of the distinction between trespass and negligence, so far as onus of proof is concerned, was referred to, with particular regard to a possible need for change in the law. However, the Manitoba court expressed the opinion that any change that was deemed necessary and desirable would have to be made by a higher court, presumably the Supreme Court of Canada, to whom the point would seem to be open for final decision. ${ }^{75}$

\section{IV}

This leads to the question of the acceptibility of the present situation in Canada in the light of the changes that have taken place in the reasoning and attitude of English courts in recent years. Any change might be limited to onus of proof; or it might go further and embrace an alteration in the entire philosophy of the law with regard to personal injuries. Both these matters need discussion.

A question which inevitably arises is whether the different attitudes with respect to onus of proof have any real, practical effect. At first sight it would seem that the position of the defendant is more difficult in a trespass case as compared with one of negligence. However, the effect of the doctrine of res ipsa loquitur may be to equalize the situation of a defendant whether he is sued in trespass or negligence. This is not completely so, of course, because in any negligence case

\footnotetext{
70 [1966] Argus L.R. 513.

71 [1967] 1 O.R. 203.

72 Id., at 210.

73 (1968) 67 D.L.R. (2d) 31.

"Supra, n. 13.

75 Id., at 328-329.
} 
there are problems about the applicability, as well as the application of the res ipsa loquitur doctrine. This is not the place to enter into a detailed discussion of that doctrine. ${ }^{76}$ It suffices to point out that the cases leave open many issues which that doctrine raises. There has been much judicial and academic discussion of res ipsa loquitur, the net effect of which is that this is an area of the law that is shrouded in ambiguity and uncertainty. That being so, it would be dangerous to conclude that whatever differences there might be between trespass and negligence so far as proof were concerned could be bridged or corrected by an application of the notion of res ipsa loquitur. Although the suggestion has been made judicially ${ }^{77}$ that any such differences have been, or could be narrowed by the application of that doctrine, it may be suggested to the contrary that there is no easy solution to be found by taking shelter in the apparently comforting intellectual warmth of the res ipsa loquitur doctrine. If this cannot be done, therefore, then a real and vital distinction remains between a case of trespass and one of negligence, as long as the onus of proof differs according to the nature of the plaintiff's claim. In Canada it would seem that legislation would be necessary to make any change, unless the Supreme Court can be persuaded to alter the opinions expressed, possibly obiter, by a minority of judges in Cook v. Lewis. Should such a change be introduced? Those in favour might well argue, with the judges in the Court of Appeal in Letang v. Cooper that to retain the differentiation is to perpetuate archaic distinctions which have long outlived their purpose and meaning. They might also argue, with Diplock J. in Fowler v. Lanning, that since the law has accepted that the onus lies on the plaintiff in cases involving accidents on, or adjacent to the highway, there seems no logical, even if there might once have been a technical, legal reason for making any distinction between accidents occurring there and those occurring on private property. At the same time, however, it may be pointed out that the development of the English cases in respect of nuisance causing personal injury seems to have been that there is a distinction between nuisance as between private landowners and nuisance on or to the highway. The former results in strict liability. The latter rests upon negligence, the onus of proving which is on the plaintiff. ${ }^{78}$ Both kinds of action stem from the action on the case: yet are treated differently. Why, then, should the same sort of distinction not obtain as between negligence (which was once case) and trespass (which never was)? There is a significant legal, as well as sociological difference between incidents on the highway and incidents on private property. Whether one likes to talk in terms of acceptance of ordinary risks, as was the basis of the judgments in Holmes v. Mather; or in terms of the more onerous duties on landowners, as compared with mere users of the highway; or in terms of the way in which an injury can be inflicted; there may be some justification for making a difference between one kind of situation and another.

78 Wright, supra, n. 52 at 41-75: Fridman, The Myth of Res Ipsa Loquitur, (1956) 14 U. of T. L.J. 233; Fridman, Res Ipsa Loquitur, (1959) 109 L.J. 36; (1970) 120 N.L.J. 180.

"Dahlberg v. Naydiuk, supra, n. 13.

7n Wringe v. Cohen [1940] 1 K.B. 229; Davy v. Harrow Corp. [1958] 1 Q.B. 60; Bolton v. Stone [1951] A.C. 850; Hilder v. Associated Portland Cement [1961] 1 W.L.K. 1434. Cf. in Canada Cooke v. Lockeport (1969) 3 D.L.R. (3d) 155. See, generally, McLaren, Nuisance in Canada in Linden, supra note 77, at 333-370. Note the element of foreseeability as regards damage introduced by the Privy Council in The Wagon Mound (No. 2) [1967] 1 A.C. 617. 
Contenders for the more revolutionary view might well argue that, since what are involved in all such instances are personal injuries, however caused, there should be no fundamental difference as to the plaintiff's chances of success by reason of any difference with respect to proof. There appears to be an element of truth in this at first sight. But, on closer inspection, some differences emerge. Despite the arguments of Lord Denning, it may be suggested that there is a difference between the direct infliction of personal injuries and a more indirect harming of another by an act which is not normally dangerous but becomes so through its negligent performance or the addition of some factor which smacks of negligence. This is not a re-incarnation of the dangerous chattles per se, dangerous chattles sub modo dichotomy. ${ }^{79}$ It is simply a recognition of the fact that some difference can be drawn between acts which are potentially harmful in themselves and those which are not usually so but are rendered dangerous by reason of the manner in which they are carried out. This, I think, might have been at the basis of the mediaeval distinction between trespass and case. It is still valid in a factual sense, even if it is not entirely well-founded in law. The very least that this factual difference should lead to, in the context of legal rules, should be some difference with respect to onus of proof. Make it more difficult for the person perpetrating an obviously potentially dangerous act to clear himself of any responsibility for the consequences of his actions. That seems to be the underlying explanation of the trespass cases, even though, as the recent Manitoba case reveals, the actions of the defendant may not involve the use of any per se dangerous thing or the commission of any per se dangerous acts or activities such as might invoke the application of the Rylands v. Fletcher principle. Such an approach, while recognizing the need for making trespass liability stricter than liability for negligent acts, does not go to the extreme lengths of creating any absolute liability for a direct infliction of personal injuries.

What kind of personal injuries are comprehended in this context? In recent years much has been heard about the possibility of recovery for nervous shock and for invasion of privacy. Is this to occur on the basis of trespass? Or as a result of negligence liability? There may be scope here for distinguishing between physical injuries directly inflicted, which would be remediable by trespass, and other types of injury, not physical in their nature, although having a close connection with such injury, for example, where shock results from fear of direct physical injury or the sight of such injury inflicted upon a spouse or relative, or where the alleged invasion of privacy results not only in economic loss, but in some kind of personal harm and inconvenience, as in Robbins v. C.B.C.80 It could well be argued that the law ought to sharpen the distinction between different consequences of an invasion of personal safety, security, or way of life, by providing a distinct remedy, juristically speaking, each governed by different substantive and procedural rules, thereby recognizing that the attitude of the law is not the same whatever the complaint of the plaintiff.

This is also reflected in the problem of remoteness of damage. With the larger issues of this I am not concerned. The relevant question

\footnotetext{
79 Which no longer obtains: Griffith v. Arch Engineering Co. [1968] 3 All E.R. 217; Dahlberg v. Naydiuk, supra, n. 13.

co Supra, n. 7
} 
in the present context relates to the applicability of the foreseeability test, as it has been utilized in negligence cases, to instances of trespass to the person. If this is the proper test to apply to a remoteness problem that arises on consequence of an alleged trespass having been committed negligently (a different situation might obtain in respect of an intentional trespass), then the similarity between, or assimilation of trespass and negligence is established. If some other test is applicable, then there is a vital practical, as well as theoretical distinction between trespass and negligence, such as involves the necessity for clarifying whether an action is one of trespass or not. The attitude adopted by the Court of Appeal in Letang v. Cooper suggests that the members of that court would have been prepared to invoke the foreseeability test in relation to what would have been trespass to the person in earlier days. The maintenance of the differentiation between trespass and negligence on the part of Canadian (as well as Australian) courts suggests that there might not be the same willingness to apply principles that govern remoteness issues in cases of negligence to a case of trespass. There are many decisions, especially in relation to trespass to land, where personal injuries have been suffered in consequence, in which a test of directness, reminiscent of the older doctrine in $R e$ Polemis, ${ }^{81}$ has been applied. ${ }^{82}$ Admittedly, the point is still open for determination (even by courts in England, irrespective of the success or otherwise of the attempted assimilation of trespass and negligence). The way in which the Privy Council interpreted the law of nuisance as regards remoteness of damage in The Wagon Mound (No 2) ${ }^{83}$ may point to the ultimate conclusion to be reached by the law with respect to other torts, including trespass in all its forms. However, that judgment is not beyond criticism; ${ }^{84}$ moreover there is still much debate possible as to the acceptability of The Wagon Mound (No 2) (and even the first Wagon Mound case) .on the part of Canadian courts.85 What concerns me in this article is whether it is legitimate to incorporate into the law of trespass to the person the entire corpus of law which has developed with respect to remoteness of damage in negligence, together with the accompanying corpus of law that has been concerned with the causation aspects of the remoteness issue. In the light of what I have suggested earlier as to the reasonableness of a distinction between different classes of actions, there would appear to be a rational basis for attempting to prevent the obfuscation of the law of trespass by shrouding it in the mysteries of remoteness as understood (if "understood" be correct) in the context of negligence.

It seems to me that, the law of negligence having become exceedingly complex and involved in recent decades, there is scope for keeping the law of trespass to the person relatively simple and straightforward. That can be achieved by maintaining the present distinction between the two types of wrong; entrenching the distinction between a direct infliction of injury and one that is indirect; even retaining the difference as to onus of proof that has emerged in the Canadian and Australian cases, while it has been abondoned by courts in England.

\footnotetext{
8) [1921] 3 K.B. 560.

82 See Wright's Cases on the Law of Torts, 4th Edn. at 73-76.

*3 [1967] 1 A.C. 617.

s4 Fridman, supra, n. 1 at $180-182$.

as Cote, Is the Wagon Mound Good Law in Canada? (1969) 47 C.B.R. 292
} 
There is no need, here, for any slavish emulation of the English example, especially when what has been done by English courts is susceptible to criticism. Even if one accepts that the forms of action are dead and buried and should not rule us from their graves, and that even their ghosts should be ignored, that is not to say that all history should be forgotten. It may well be that cessante ratione cessat ipsa lex, but can it be said in this context that the reason has ceased to operate? On the basis of the arguments put forward earlier, I would submit that there is still room for the difference between trespass and negligence. Whether some development along the lines suggested in England vis-a-vis onus of proof ought to take place in Canada, is another matter. I am not convinced, though the Court of Appeal in Manitoba appear to have been, that change is necessary, for reasons which I have attempted to outline above. Even if that change is desirable, I do not consider that it renders necessary the further alteration in legal outlook represented by the judgments in Letang v. Cooper. There is a case to be made for the relevance of trespass in modern law. I hope I have managed to make it satisfactorily. If not, then perhaps the discussion and suggestions in this essay will lead someone else to do so. 